Journal

of Geography,

Politics and Society

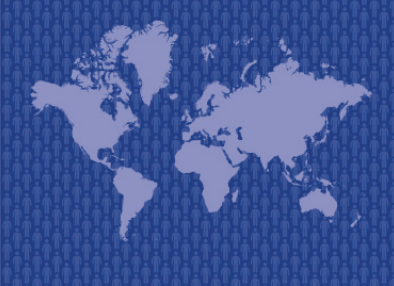

$10(3) / 2020$

\section{Journal of Geography, Politics and Society}

2020, 10(3), 5-15

https://doi.org/10.26881/jpgs.2020.3.02

\title{
RETHINKING THE TOPONYMIC POLITICS IN BELARUS IN THE 20 - 21 CENTURIES: TOWARD THE POST-COLONIAL PERSPECTIVE
}

\author{
Sergei Basik \\ School of Interdisciplinary Studies, Conestoga College, 299 Doon Valley Drive, Kitchener N2G4M4, Canada, ORCID: 0000-0002-5952-7515 \\ e-mail: sergei.basik@gmail.com
}

\section{Citation}

Basik S., 2020, Rethinking the toponymic politics in Belarus in the 20 - 21 centuries: toward the post-colonial perspective, Journal of Geography, Politics and Society, 10(3), 5-15.

\begin{abstract}
The article explores the historical trends and patterns in the politics of space in toponymic landscapes of Soviet and postSoviet Belarus through the prism of critical toponymy and the post-colonial theoretical approach. This work aims to reveal the colonial essence of the toponymic politics and policies in Belarus during the Soviet era and explore the unique national (post) colonial context of the post-independent place names. Based on the idea of methodological convergence of post-colonial and post-socialist paradigms, this article analyzes the "top-down" hegemonic toponymic practices implemented by the Soviet regime in Belarus in comparison with the place name policies of the colonial regimes in other parts of the world. Using the comparative analysis of historical (re)naming cases from the regional toponymic system of Belarus, the work shows that the Soviet regime used similar goals, methods, and technologies as other colonial powers. Such examples include ignoring the national language, history, and cultural traditions reflected in place names, inadequate renaming criteria and arrogant methods of choosing the new names, banalization of toponymic landscape and inconsistency in renaming, removing the Belarusian vocabulary from the toponymic landscape and inserting the foreign words and terms into the toponymic system, phonetic and grammatical mutilations of national toponyms according to the norms of the foreign language, symbolic resistance of local population toward new place names. The post-independent period can be defined by the selective post-colonial toponymic practices, which include the co-existence of the Soviet and national toponyms, symbolic (re)naming processes typical for new independent post-colonial states, and the resurrection of the ideologically motivated "toponyms-zombies" from the previous period. Therefore, the modern toponymic landscapes in Belarus can be considered post-colonial, and methodological and theoretical post-colonial perspectives on toponymic research can be applied to post-socialist states.
\end{abstract}

\section{Key words}

political toponymy, spatial politics, post-socialism, post-colonialism, Belarus.

Received: 10 June 2020 Accepted: 30 August 2020 Published: 30 September 2020 


\section{Introduction}

In the last two decades, perhaps, since the groundbreaking essay by D.C. Moore (2001), the post-colonial theory, as a relatively new methodological approach, has been cautiously applied toward the analysis of the post-socialist world. Consequently, despite the abundant amount of criticism, epistemological problems, and solid arguments against, such as the role of the USSR in modernization and political mobilization of its regions (Adams, 2008), many scholars asserted that the numerous "overlaps" between post-socialism and post-colonialism have multiple reasons "for treating the communist imposition in east-central Europe as a particular historical embodiment of a persistent and widespread imperial drive" (Kołodziejczyk, Şandru, 2012, p. 115). For instance, some commentators argue that the orders in the Russian Empire and its successor, the Soviet Union, "were clearly colonial in character" (Lazarus, 2012, p. 118). Not surprisingly, due to the unique historical past and the distinctive geopolitical location on the borderland (or a crossroad) between the West and the East in the middle of the European continent, the post-Soviet country of Belarus serves as "a distinctive case study for the intersection of memory and (post)coloniality" (Lewis, 2019, p. 14). Intrinsically, the post-colonial methodological approach on Belarus has been used in a wide range of recent studies produced both by the scholars working in Belarus and Western academic institutions (Babkoú, 1999; Abušenko, 2004; Akudovič, 2007; Bobkov, 2008; Oushakine, 2013, 2017; Bekus, 2017a).

The politics of space in the colonial and postcolonial world as well as the (geo)political and socio-economic problems, which were reflected in contested toponymic legacy and its transformations, are well discussed in contemporary political toponymic scholarship (Yeoh, 1992, 1996; Azaryahu, 1996, 2011, 2019; Nash, 1999; Berg, Vuolteenaho (eds.), 2009; Bigon (ed.), 2016; Rose-Redwood et al., 2017; to name but a few). Essentially, the colonial power inserts "the mental images" of the colonizers (Yeoh, 1992). As a result, different toponymic systems shared similar semantic goals and characteristics that reflected in "an imaginative process of 'othering' and 'peripheralizing' the colonized populations" (Bigon, Njoh, 2015, p. 37-38). For instance, in the cities, the impact of colonialism on the place naming is connected to the administrative regulation of urban spatial order, the commemoration of colonial "heroes" and officials, and, sometimes, can cause a co-existence of national and colonial place names systems (Azaryahu, 2011). As"a place-making strategy to reinforce the colonial hegemony and ideologies" (Wanjiru-Mwita, Giraut, 2020, p. 12), toponyms have been used in different parts of the (post) colonial world. Mostly, for the colonizers, the place names serve as an element of "a larger process of colonial cultural and political subordination" (Nash, 1999, p. 461). In some cases, the politics of colonial power can be ambivalent (Hui, 2019).

In the framework, which interprets the geopolitical contexts of (re)naming, F. Giraut and M. Houssay-Holzschuch (2016) distinguished four main categories that "not mutually exclusive, but do overlap" (Giraut, Houssay-Holzschuch, 2016, p. 9): conquest (including imperial, colonial, national), revolution (a complete change of political system), emergence, and commodification. Remarkably, much of the critical toponymic publications in recent decades were related to two main types of geopolitical changes: colonial to post-colonial and socialist to post-socialist (Rose-Redwood et al., 2017, p. 17). Unsurprisingly, these two streams of scholarship often merge when connected to the post-Soviet toponymic cases. For instance, in the case of the largest city in Kazakhstan, Almaty, the post-independence place-naming policies adopted a mix of typical post-colonial toponymic strategies (Shelekpayev, 2017). Recent toponymic transformations in Ukraine as a result of decommunization of landscape can be classified as related to the changes of political regimes, and, at the same time, as the reflected post-colonial and ethnic/nationalistic discourses (Gnatiuk, 2018). In some cases, the authors are talking about the Ukrainian toponyms as an example of "linguistic colonization" or even "occupation" (Demska, 2016, p. 607). It seems that the reasonable question is if the post-colonial methodological approach can be fully or partially applied towards the analysis of the toponymic systems of post-Soviet, or, even, the entire post-socialist world.

Thus far, there has been a minimal number of attempts to apply the post-colonial approach for the critical analysis of the political toponyms in Belarus in the 20-21 centuries. The only exceptions are the work of S.N. Basik and D.A. Rogovcov (2017), where the authors sporadically mentioned some similarities between the colonial toponymic politics and the examples of hegemonic toponymic practices in Soviet-era Belarus, and the interpretation of the Minsk's main street renaming from the point of view of post-colonial theory by S.A. Oushakine (2017). The current paper addresses this under-researched component of the post-Soviet place-name studies.

This work is theoretically based on the idea of a methodological convergence of both post-socialist and post-colonial paradigms. Using a critical toponymic approach and driven upon Belarusian 
toponymic materials, this study formulates two key goals: 1) to reveal the colonial essence of the toponymic politics and policies in Belarus during the Soviet era, comparing and contrasting them with the well-known colonial examples around the globe; 2) to explore the unique national (post)colonial context of the post-independent toponyms in Belarus. It is also crucial to consider all these questions from the Belarusian national perspective.

\section{Data and Methods}

In this work, I concentrate attention on place names both from diachronic and synchronic perspectives and apply some quantitative interpretations and historical toponomastics methods through the lens of the critical toponymic approach. Throughout, I also use the elements of comparative analyses of place names in Belarus and different world regions. This paper is focusing on Soviet-era and post-independent toponymic examples, policy and practices without considering other significant historical periods in 20 century, such as the Russian empire (up to 1917), Poland (western part of Belarus, 1921-1939), or The Third Reich occupation (1941-1944). Some examples from these periods are considered only tangentially.

The data for the analysis includes several sources such as cartographic and archival materials, the author's in situ observations in 2000-2009 (the city of Minsk and the Brest region settlements), and a list of 450 place names renamed from 1918 to 1972 (Žučkevič, 1974, addendum, p. 439-447). I explore the key patterns of the Soviet toponymic changes mostly based on oikonyms, the names of the settlements. Importantly, some toponymic examples in this research also include hydronyms, the names of the hydrographic objects, oronyms, the names of the orographic objects, hodonyms, the urban street names, and urbohoronyms, the names of urban administrative regions.

Indeed, there are shortcomings with the list of 450 place names: for example, not $100 \%$ of all the renamed place names were included, and the renamed toponyms after 1972 were not analyzed. However, as per the paper's goals, these materials and data are evident and show the dynamics, extent and general nature of the Soviet period toponymic transformations in Belarus, which is crucial for the comparative post-colonial analysis.

Additionally, in this work, as a historical toponomastics method, I apply a slightly modified general classification of urban place names (Stiperski et al., 2011; Basik, Rahautsou, 2019) and discuss six semantic naming categories: 1) persons; 2) history; 3) geography; 4) professional activities, institutions; 5) descriptive and euphonic; 6) other. This classification is applicable toward the list of 450 oikonyms because they are not formed as a result of the natural process of toponymic formation. Instead, they are artificially created by the Soviet authorities, in the same way as the urban place names, which are, in most cases, also artificially created features of the urban landscapes. Some limitations in this and other similar classifications are related to the polysemantic qualities of some place-names that might be included in two or more categories (see more Basik, Rahautsou, 2019, p. 110). The Latin transliteration of Belarussian place names in this study is provided according to The Roman alphabet transliteration of Belarusian geographical names (2012), the official international document, adopted by the United Nations.

\section{Results and Discussion}

For the territory of modern Belarus, the period of 1917-1920 included the WWI, two revolutions and the collapse of the Russian empire in 1917, the German occupation in 1918, the Russian Civil War, the war between Poland and Soviets in 1920 with the Polish occupation and the Bolshevik's recapturing. During these years, there were "no less than six attempts" at declaring Belarusian state (Rudling, 2014). Among them, the Belarusian People's Republic, which remained independent less than a year in 1918, was the only one real attempt to establish the national sovereign country, but the Red Army regained this territory again. In 1921, after the partition of the Belarusian lands between Poland (received Western Belarus, 1921-1939) and Soviet Russia as a result of the Riga treaty, the Bolsheviks "easily adopted and adapted" the imperial national identity, and the "Russian and Soviet identities were closely intertwined" (Forest, Johnson, 2002, p. 527). In 1922, Soviet Bielorussiya became one of the "creators" of the Soviet Union. Consequently, since the first years of Soviet power, despite the policy of korenizatsiia ("nativization") in the 1920s, new place names were entered into the toponymic system, and Belarusian national vocabulary was partially deleted from the toponymic landscape following the (re)naming practices.

Accordingly, for the place names of Belarus, there were several "waves" of renaming (fig. 1).

One "wave" was related to a specific period, a Stalin era before WWII, when 69 place names were renamed in 1938-1939. However, the most destructive 


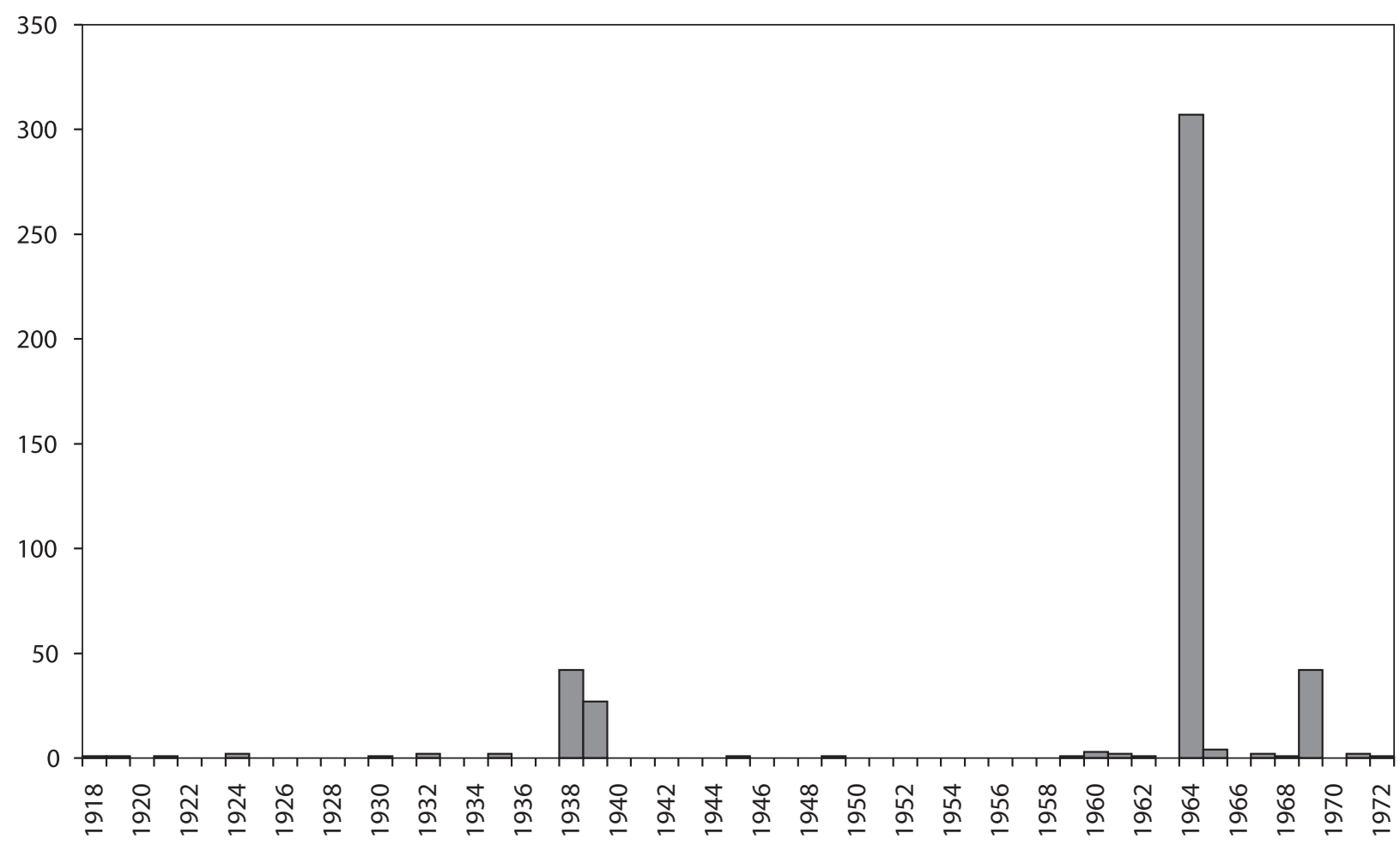

Fig. 1. The temporal dynamics of place names renaming in Soviet Belarus (1918-1972)

Source: Žučkevič (1974, addendum, p. 439-447), compiled by the author.

period was the "wave" of the 1960s. In particular, 307 place names (68\% of the analyzed renamed toponyms) were changed in 1964, and 42 toponyms were renamed in 1969. Analyzing the list of place names from the historical toponomastics perspective, I distinguish several semantic groups:

- religious toponyms, e.g. Ihumien (hegumen, abbot), Manastyr (monastery), Papoŭka (pop means priest), Dziaki (deacons), Carkoǔščyna (carkva church), Ikonki (icons);

- toponyms reflect (or similar to) the names and titles of kings, tsars, nobles, landlords, e.g. Kniažyca (kniaź means duke), Karali (kings), Caroŭsk (car - tsar), Panskaje (pan - landlord), Šliahtoǔščyna (šliachta - gentry), Ramanava (the Romanov dynasty);

- place names that remind the surnames of the White army generals and other enemies of the Soviet power, e.g. Judzieničy, Karnilavičy (the Russian White army generals);

- toponyms reflect the elements of the previous social, economic and administrative systems and relationships, e.g. Majontak (estate), Faĺvarak (manor), Poddanyja (servants), Haspody (masters), Halopkavičy (halop - serf);

- place names that reflect "foreign" origin or "foreign" place names, e.g. Aŭhustbierg, Amieryka, Mar' janfieĺd, Ershtermaj;
- toponyms usually originated from the local nicknames and terms, that show the poor social and economic conditions of the local population, e.g. Biaschlebičy (no-bread people), Machajedy (moss-eaters), Lukajedy (onion-eaters), Halodničy (halodny - starving), Biadovičy (biada - trouble);

- profane toponyms usually originated from the local nicknames, e.g. Blievačy (bliavać - to vomit), Durnievičy (durni - idiots), Neumyvaky (unwashed), Pliašyŭcy (bald);

- place-names originated from the local nicknames with "animals"' roots, e.g. Barany (rams), Byki (bulls), Kabyličy (kabyla - mare), Kazly (goats), Tarakany (cockroaches);

- ancient Belarusian place names which are homonyms to modern Russian terms with negative connotations, e.g. Marhi (morh is a medieval measure of length, but a modern Russian homonym morg means morgue), Zascienki (zasceinak is a medieval type of settlement, but a modern Russian homonym zastenok means jail), Jazvy (jazvy a local physiographic term "natural pond," but a modern Russian homonym jazva means ulcer). Notably, most of these toponyms were unaccepted from the standpoint of communist ideology and were eventually destroyed by the Soviet renaming practices. Admittedly, the toponymic system was viciously cleansed from ideologically "wrong" place names (religious, pre-Soviet powerful figures 
such as kings, tsars, nobles). Remarkably, however, that, at the same time, the renaming process was characterized by inconsistency, especially for the toponyms originated from the nicknames and the socio-economic terms. Very often, the same forms of place names were deleted in one region but kept untouched in another part of Belarus. For example, three toponyms Kabak, Kabaki (kabak - in Russian Empire, a tavern, a pub) were renamed, whereas the same place names in other regions (e.g. Liepielski and Biarozaúski districts) were not changed and still exist. This aspect can probably be explained by the different understanding of renaming criteria by regional authorities, unprofessionalism, and other local factors.

One more critical aspect of the toponymic renaming in Soviet-era Belarus is the semantic assortment of new names attached to the places (tab. 1).

Pure ideological motif and the tradition of inserting the commemorative place names from the communist "iconostases" (Persons category, Soviet subcategory) and from the list of the Soviet propaganda and communist mythology (History category, Ideologemes, dates, symbols subcategory) on Belarusian regional toponymic landscapes correspond with the similar trends in socialist, revolutionary and transitional societies. These names play an important role in the mythicization of toponymic landscapes (David, 2011). Thus, for the names of Soviet Persons, some typical examples include the names of the communist leaders such as Lenin (toponyms Lienina - four examples) and the derivates from his original family name Ul'yanov and patronym II'ych, Kirov, Dzerzhinskiy, Volodarskiy, Uritskiy, Sverdlov. Among other personalities, the name of the Soviet aviator V. Chkalov was an example of the late 1930s (two toponyms).

The historical subcategory of Ideologemes, dates, symbols, which is the second largest in this classification and acquires $17.1 \%$ of the renamed names in the analyzed period, can be characterized by the various semantic assortment of miscellaneous communist terms. For instance, they include the important dates from the Soviet ideological calendar - the 1st of May (Pieršaje Maja, Majskaje, Peršamajskaja), October (Russian forms of toponyms simply inserted and transliterated - Akciabr, Akciabrski, should be Belarusian Kastryčnik, Kastryčnicki); the key terms,

Tab. 1. Semantic naming categories of renamed toponyms in Belarus in 1918-1972

\begin{tabular}{|c|c|c|c|c|}
\hline Category & Subcategory & Group & Percentage & Toponymic examples \\
\hline \multirow[t]{7}{*}{ Persons } & \multicolumn{2}{|l|}{ Pre-Soviet } & 0.8 & Kutuzaúka \\
\hline & \multirow[t]{3}{*}{ Soviet } & Communist leaders, personalities, heroes & 6.0 & Dziaržynsk \\
\hline & & WWII & 0.9 & Zaslonaúka \\
\hline & & Culture, science, and technology & 0.5 & Haharyna \\
\hline & \multicolumn{2}{|l|}{ International } & 0.2 & Roza Liuxemburg \\
\hline & \multicolumn{2}{|c|}{ Unclassified anthroponyms } & 3.8 & Ivanaúščyna \\
\hline & \multicolumn{2}{|c|}{ Whole category } & 12.2 & \\
\hline \multirow[t]{3}{*}{ History } & \multicolumn{2}{|c|}{ Ideologemes, dates, symbols } & 17.1 & Savieckaja (Soviet) \\
\hline & \multicolumn{2}{|l|}{ WWII } & 3.9 & Peramoha (Victory) \\
\hline & \multicolumn{2}{|c|}{ Whole category } & 21.0 & \\
\hline \multirow[t]{9}{*}{ Geography } & \multicolumn{2}{|c|}{ Belarussian place names } & 3.6 & Paliesse, Narač \\
\hline & \multirow{5}{*}{$\begin{array}{l}\text { Physiograph- } \\
\text { ic toponyms }\end{array}$} & Topography & 2.7 & Hornaja (Hilly) \\
\hline & & Hydrography & 2.2 & Kryničnaja (krynica - spring) \\
\hline & & Phytotoponyms (plants) & 26.0 & Višneúka (višnia - cherry) \\
\hline & & Zootoponyms (animals) & 1.3 & Sakaloúka (sokal - falcon) \\
\hline & & Other & 0.5 & Kamienka (Stoney) \\
\hline & \multicolumn{2}{|c|}{ Locational/spatial } & 10.2 & Padliesse ("not far from the forest") \\
\hline & \multicolumn{2}{|l|}{ Ethnic names } & 0.2 & Slavianka \\
\hline & \multicolumn{2}{|c|}{ Whole category } & 46.7 & \\
\hline \multicolumn{3}{|c|}{ Professional activities, institutions } & 2.4 & Saúchoznaja (Soviet farm) \\
\hline \multicolumn{3}{|c|}{ Descriptive and euphonic } & 14.4 & Svietlaja (bright) \\
\hline \multicolumn{3}{|c|}{ Other (unclassified) } & 3.3 & Krasieúka \\
\hline \multicolumn{3}{|c|}{ All categories } & 100.0 & \\
\hline
\end{tabular}

Source: Žučkevič (1974), compiled by the author. 
symbols and signs of the communist party and the Soviet state - bolshevik (Baĺšavik), Soviet (Savieckaja), the red flag (Sciah, Čyrvonaje Znamja, Znamienka), the star (Zviazda), the red color in general (Čyrvony Majak - red lighthouse, Čyrvony Uschod red sunrise, Čyrvony Pasiolak - red settlement); the names of the communist newspapers (Iskra - spark, Praúda - truth); the names of the pre-Soviet socialist movements (Paryžskaja Kamuna, Kamunarka, Kamunar - all related to the $19^{\text {th }}$ century Paris Commune); the names of the communist and Soviet military units - red army (Čyrvonaarmejskaje); the name of the communist youth organization (Kamsamoĺskaje), and other.

However, despite the vital symbolic role of the ideologically motivated toponyms for the Soviet regime, almost half of the newly minted place names (46.7\%) belong to the Geography category. The simplified, randomly chosen, banal physiographi$\mathrm{cal}$ and locational names given to the settlements reflect a typical colonial attitude towards Belarusian toponyms. Primitive locational/spatial names that comprise $10.2 \%$ of all toponyms renamed in 1918-1972, simply reflect the spatial position of the settlement with the local natural objects such as forest (Zaliesnaja), river (Pryrečnaja), lake (Zaaziernaja). Thus, the monotone and semantically identical place names inundated the toponymic landscape of Belarus.

Phytotoponyms, or the place-names originated from the names of plants, is the most represented subgroup of renamed place names in this period acquiring more than a quarter of all renamed toponyms (26\%). Among them, there are the common plant names for the Belarusian toponymic landscape (birch - Biarozaúka, pine - Sasnovaja, coniferous forest - Baravaja). At the same time, frequently the names of vegetation chosen by the Soviet authorities include various types of berries, fruits, and fruit orchards, which is an unusual segment for the national toponymic system: cherry (Višneúka, Višnia, Višniovaja, ten toponyms), raspberry (Malinavaja), pear (Hruša), red viburnum (Kalinavaja), rowan (Rabinavaja), berry (Jahadnaja), fruit orchard (Sadovaja). Importantly, these "fruity" and "sweet" place names were not just banal and neutral: they could ideologically and symbolically represent an "idyllic" life of the Soviet peasants in the Soviet village. Some Russian plants' names were inserted in toponymy without any connections or adaptations to the Belarussian language. For instance, the authorities used the Russian term sirien' (lilac) instead of Belarusian bez to create the toponym Sirenevka (in Russian), which is transliterated Siareneúka in Belarussian and exists as a foreign place-name for the locals.
One more interesting category, which comprises $14.4 \%$ of the renamed toponyms, is Descriptive and euphonic names. Their neutral and positive connotations played the same role as mentioned earlier "fruity" phytotoponyms: Mirnaja (peaceful), Svietlaja (bright), Sonečnaja (sunny). Among this category, many Russian terms were simply inserted in the local toponymic system: Raduga (rainbow, viasiolka in Belarusian), Družba (friendship, siabroústva in Belarussian), Lučezarnaja (radiant, pramianistaja in Belarussian). Without any doubt, this category of names also played a crucial role in the Russification and erosion of the Belarusian national toponymic landscape. Besides the spatial politics of Russification, the toponymic illiteracy of the Soviet authorities responsible for renaming can be explained by the complete arrogance towards the Belarusian national culture, history, and language. Even structurally, from onomastics, these oikonyms remind the artificially created street names. Remarkably, based on the data of the Register of Street and Road Names, in 2019 among the top five street names in Belarus were similar Locational and Descriptive/euphonic place-names: Centraĺnaja (Central, 5161 names), Maladziožnaja (Youth, 2171 names), Sadovaja (Orchard, 2170 names), Liasnaja (Forest, 2108 names), and Paliavaja (Field, 1639 names) (V Nacional'nom..., 2019).

The politics of place renaming in Belarus involved not only oikonyms but also the names of some physiographical objects, first of all, lakes. Hence, in 1932, the largest lake in South Belarus, Kniaź-Vozera (duke the lake), received a new ideologically correct name, Čyrvonae (red). Besides, in 1958, the highest point in Belarus, Sviataja Hara (Holly Hill), had gotten a new name Dziaržynskaja. This name from the Soviet pantheon correlated with the location of the hill, not far from the town of Dziaržynsk (former Kajdanava, renamed in 1932). The role of these objects as the unique elements of the physiographical landscape and their "unacceptable" names for Soviet authorities were the main reasons for renaming. This process was typical not only for the USSR (such as for the Pamir Mountains, see Horsman, 2006) but also in colonial and post-colonial regions around the globe. For instance, during the European conquest, the Great African Lakes received the names of kings and queens (Lake Victoria, Lake Albert, Lake Edward). Remarkably, in the post-colonial period, some of these lakes were renamed and received the names of local dictators (Lake Albert - Lake Mobutu Sese Seko, Lake Edward - Lake Idi Amin Dada). However, after the fall of the dictatorship regimes in Zaire and Uganda, the colonial names were returned to these objects again, even though they have various local names in African languages. 
One of the most important characteristics of the toponyms in Belarus is their grammatical and phonetic form, which was transformed and mutilated according to the requirements of the foreign languages, the languages of colonizers. The place names experienced "profound standardization to conform to the linguistic norms and tastes of the colonizing powers" (Saparov, 2017, p. 535). The regional geopolitical powers have constrained the long-suffering Belarusian toponymic system for centuries. Since the 16th -17 th centuries, when the Old Belarusian language's status as an official language in the Polish-Lithuanian Commonwealth was abolished, the Belarusian place names were encrypted on the maps and documents in Polonized phonetic and grammatical forms. During this period, the Belarusian toponyms were affected by the colonial supremacy of the Polish cultural pattern when "the dominant Polish culture and the mostly folkloric culture of nations under Poland's domination" (Fiut, 2014, p. 37) co-existed. After the Polish-Lithuanian Commonwealth partition in the late 18 century, the Belarusian lands were grabbed and attached to the Russian Empire. During the Russian imperial period, the altered, foreign for the locals, Polonized forms were just re-written in Russian Cyrillic graphics, with uncharacteristic phonetics, grammatical and word-forming features (Lemcûġova, 2010). Besides, many Belarusian toponyms were transformed according to Russian language tradition, and they are still in use in the 21st century. For instance, the Belarusian toponyms with the ancient formants - aú, -oú, -ieú, -in (-yn) were replaced deliberately by the Russian forms with -ava, -ova, ieva, -ino: Barbaroú Barbarova, Halačeú - Halačova, Chonaú - Chonava (Lemcûgiova, 2010). During the Soviet era, in particular, in the 1960s, the Russification tendency in renaming was especially evident: the Russian terms (not only ideologically motivated) foreign to locals were entered into the Belarusian toponymic system. Similarly, analyzing the British colonial impact on the toponymic system of India, A. Kapur (2016) notices two distinct practices: Englishization (insertion of the English terms) and Anglicization (a phonetic and orthographic adaptation of Indian toponyms to the English language). Both practices also ignored the local place-names transcription and pronunciation in favor of the linguistic preferences of colonizers. In the same way, in Canadian Prairies, the aboriginal toponyms that "survived" the settlers' colonization exist in "an appropriated, translated or mangled form" (Lehr, McGregor, 2016, p. 83). Importantly, the long-term colonizers in Belarus were mostly the Slavic nations, both Poland and Russia, with the languages pretty similar to the Belarusian language.
This linguistic aspect reflects not only "the contested nature of Belarusian identity" (Bekus, 2017a), but also the contested features of national toponymies. As a result, it was easier for the colonizing power to claim its "ownership" on Belarusian toponyms and, consequently, the geographic space, frequently using "simple" phonetic or grammatical modifications of place names in order to synchronize the toponymic systems. Certainly, this is a different situation compared to the other regions of the world, for example, Africa, the Americas, or even Ireland, where the languages of the conquerors were different from the native languages of the local population.

The local use of an alternative, traditional form of toponym that is "off the radar" of an official name is a typical feature for post-colonial toponymic systems (Bigon (ed.), 2016). For the post-socialist realm, it was pointed out that the scholars "have yet to fully give voice to local residents' take on the toponymic transformations and to account for how they resist, contest, and accommodate to these shifting namescapes" (Rusu, 2020, p. 14). There are many examples of symbolic resistance of people in Belarus to administrative toponymic power. For instance, locals in everyday life still use the old name Bludeń (Biarozaúski district; etymology - from the ancient Slavic name Blud) instead of the official name Pieršamajskaja the 1st of May (Basik, Rogovcov, 2017).

As per the critical toponymic literature, the vital post-colonial strategies of toponymic de-colonization include two opposite "radical" methods: complete erasing of colonial past in toponymic landscape or saving of the colonial commemorative place names; significantly, there is also a third option where the erasing of colonial past can be selective depending on regional/local geopolitical situation (Azaryahu, 2019). Interestingly, S. Basik and D. Rahautsou (2019) distinguish several symbolic spatial strategies in the urban toponymic system of Minsk used by the authorities in post-Soviet Belarus. Among them, besides the imminent Soviet toponymic remnants, and the WWII segment related to national trauma, a slight "Belarusization" of toponyms, internationalization of the place names through the Latinization of the street signs, a reflection of the international political agenda of the independent Belarusian state, the branding goals such as the commodification of urban toponyms and promotion of Belarus as a regional IT hub, and the increasing role of the symbols of independence in urban toponyms are consonant to the similar strategies in post-colonial nations. Authorities have utilized selective postcolonial strategy (Azaryahu, 2019) based on the Belarusian regime's geopolitical preferences of nation building. Besides, all of the strategies fit with 
the mentioned earlier theoretical framework of the "overlapped" geopolitical contexts of (re)naming (Giraut, Houssay-Holzschuch, 2016).

According to the Register of Street and Road Names, in 2019 in (post)independent Belarus, there was a pretty high number of the urban place names (769) commemorated Lenin or the derivates of his name (V Nacional'nom..., 2019). However, the politics of "toponymic continuity" (Light, Young, 2017) is reflected not only in the conservation of the Soviet-era urban toponyms and oikonyms. It can also be seen in the regional administrative division of the largest cities and represents the toponymic and symbolic legacy of the Soviet period (Basik, Rogovcov, 2003). This situation is typical for many urban centers in the post-Soviet realm, such as St. Petersburg, Russia (Marin, 2017). As per the observation, there are twenty-two administrative districts (rajons) in the six most significant cities of Belarus, and thirteen names of the rajons (or 59\% of all urban rajons' names) are the Soviet ideological products: Lieninski (Lenin), Kastryčnicki (October), Saviecki (Soviet), Pieršamajski (the 1st of May), Frunzienski (Frunze). For example, the names Kastryčnicki and Lieninski exist in four cities out of six, and for the cities of Hrodna and Mahilioŭ, they are the only names of the rajons.

The (post)colonial context in Belarusian urban toponyms illustrates the never-ending alterations of the city of Minsk's main avenue's name (fig 2). As S. A. Oushakine (2017, p. 444) points out, "the multilayered colonial history reveals itself less through short-lived names than through a long sequence of their perpetual modification." The street was named Zacharievskaja in the early 19-century after the Russian Governor of Minsk, Zachary Korneev, or St. Zachary, his patron Saint - a typical toponymic "trick" of the colonial powers widely represented around the world. French, Polish and twice German occupations were also shown in colonial names. Twice in the 20th century, the avenue returned the name Vulica Savieckaja (Soviet Street).

The end of the Stalinism epoch in 1961, with an erasing of Stalin's name from toponyms, was reflected in the new name, Praspiekt Lienina (Lenin Avenue). By the way, in 1961, one of the administrative districts of the city, Stalinski Rajon, was renamed and received a more neutral "industrial" name Zavodski (zavod - factory) Rajon. Consequently, there were two names the avenue obtained during the postindependence period. Both names reflect the postcolonial ideals and include the name of the national cultural symbol, the first medieval Belarusian book printer Francysk Skaryna, and the term "independence" so prevalent in post-colonial urban landscapes (Independence Avenue in Washington, DC where the United States Capitol is located, or the names of the main streets in different African capitals).

The re-introduction of colonial names in the post-colonial period is one of the typical characteristics for some Sub-Saharan African nations (Bigon (ed.), 2016). Remarkably, in the city of Algiers, where

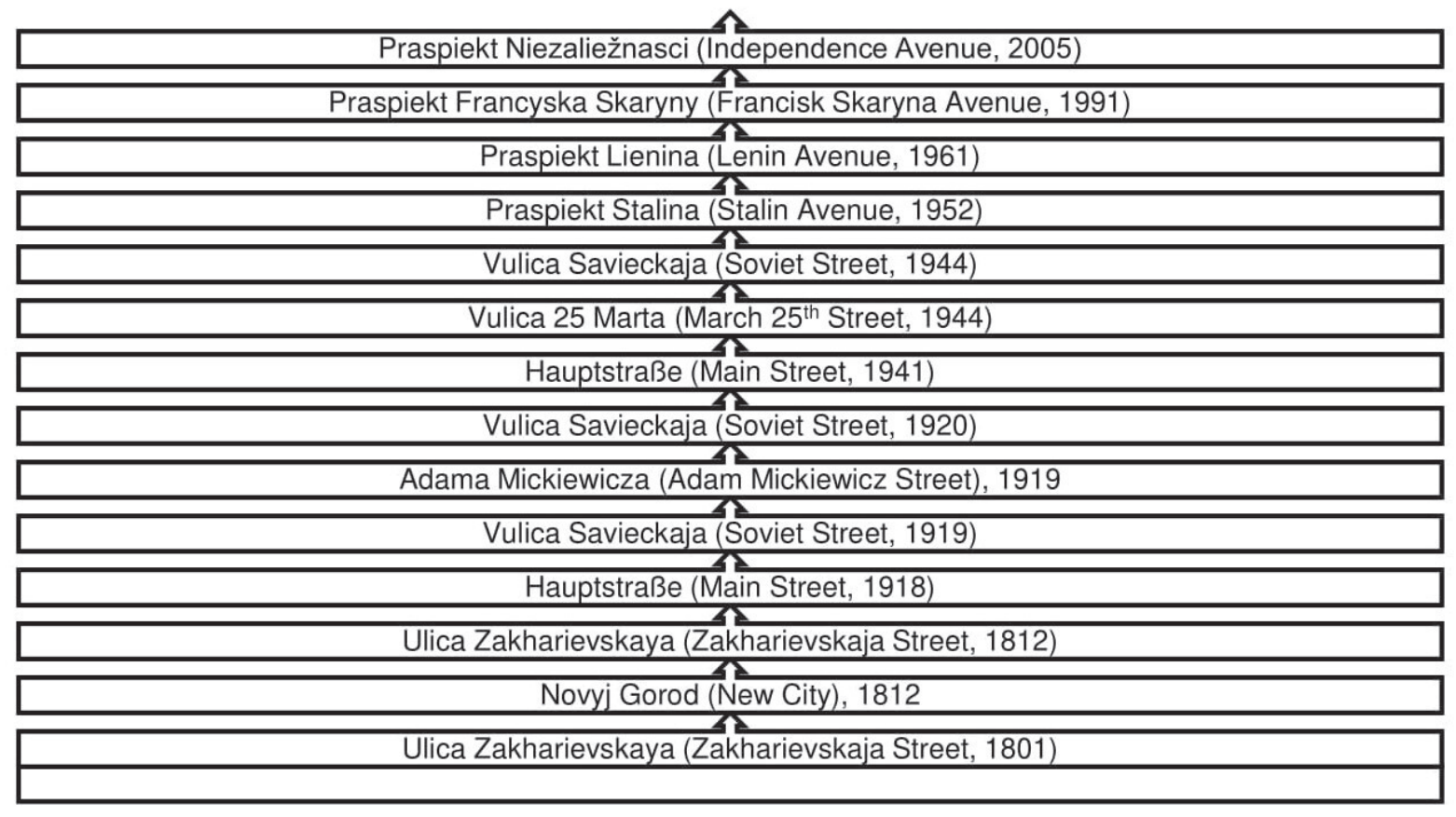

Fig. 2. (Re)naming of the main avenue in Minsk, Belarus, in the 19-21 centuries

Source: created by the author. 
during the first five years after Algeria obtained independence from France in 1962, more than 300 urban place names were renamed, many streets in the city center still go under the French-colonial names among the general public (Grabar, 2014). Notably, in Belarus, the politics of toponymic continuity and the "ideological recycling" (Bekus, 2017b) of the Soviet legacy supported by the current political regime obtain an unusual form of the symbolic resurrection of the Soviet-style "toponyms-zombies." Some examples include the names of the historical-cultural complex the Stalin Line opened in 2005 not far from Minsk or the name of the new shopping center LeninGrad opened in Minsk in 2015. The example of a shopping mall is, in particular, toponymically reflects the concept of "zombie socialism" neoliberalization (Chelcea, Druță, 2016).

Undoubtedly, such place names reflect the general narrative of the current political power in Belarus, which is symbolically oriented toward the Soviet legacy. However, there was an example of the successful de-colonization of the urban toponymic system in the 1990s. In Maladzečna (Minsk Region), the streets in the city's core were renamed and received their historical names or the new names with national semantics. For example, Lenin Avenue became Vialiki Hascinec (the Great Path), Maksim Gorky Street became Zamkavaja (Castle), Saveckaia (Soviet) became Vilienskaja (Vilna), Karl Marx Street became Ignacij Bujnicki Street (Gardzeâú, 2017). Supported by the nationally oriented local authorities and activists, the (re)naming process declined later for the political reasons, but the possible de-colonizing toponymic solutions for the future policies in Belarusian cities have been shown.

\section{Conclusion}

As per the critical toponymic theory, "the hegemonic practices of place naming do some of the heavy work of naturalizing and reinforcing the dominance of existing social orders" (Vuolteenaho, Berg, 2009, p. 14). Because the Soviet period can be considered as an imperial project, similar to the Western imperial colonial projects, the Belarusian toponymic system serves as a symbolic reminder about the ideological and imperial superiority of the "Elder brother" who implemented the strict "top-down" hegemonic toponymic practices. Importantly, however, the key patterns and practices in politics of space in toponymic landscapes of Belarus have the same characteristics as other (post)colonial toponymic systems, which often represent the consequences of "toponymic dispossession" (Tucker, Rose-Redwood, 2015, p. 198). They include several examples, briefly discussed in this paper, where one of the most important was ignoring the national language, history, and cultural traditions reflected in place names. Besides, the inadequate renaming criteria, together with the arrogant methods of choosing the new names, simplification and banalization of the toponymic landscape, and the inconsistency in the renaming process created a modified messy toponymic landscape. The process of removing the Belarusian national vocabulary and inserting the foreign words and terms often alien to the locals into the toponymic system, as well as the phonetic and grammatical transformations and mutilations of national toponyms according to norms of a foreign language, destroyed the Belarusian national toponymic landscape. A symbolic resistance of the local Belarusian population was reflected in ignoring the new artificial names and using the traditional toponyms in everyday life. The post-independent period can be characterized by the selective toponymic practices that include the co-existence of the national and Soviet toponyms and (re)naming practices of an independent national state (first of all, urban place names in the capital city) and re-introduction of the Soviet-style names through the symbolic resurrection of the "toponyms-zombies."

In conclusion, this paper shows that the Soviet regime implemented a specific form of colonization in Belarus reflected in toponymic policies and practices. Moreover, adopting such a theoretical viewpoint might open the new avenues for political toponymic research in Belarus and the post-socialist countries. Interconnections between the post-socialist and post-colonial paradigm in toponymy seem reliable though more thorough comparative analysis and detailed future conceptualization are required. Indeed, there are some understandable methodological issues and theoretical disconnections in merging the paradigms related to time, history, space, and place. However, it might be a new promising perspective for critical analysis of toponymic transformations in the post-communist realm.

\section{References}

Abušenko V., 2004, Kreol'stvo kak ino-modernost' vostočnoj Evropy (vozmožnye strategii issledovaniâ) (Eng. Creoleness as a foreign modernity of Eastern Europe [possible research strategies]), Perekrestki, 1-2, 124-156.

Adams L., 2008, Can We Apply Postcolonial Theory to Central Eurasia?, Central Eurasian Studies Review, 7(1), 2-7.

Akudovič V., 2007, Kod adsutnasci: asnovy belaruskaj mental'nasci (Eng. A code of absence: the basics of Belarusian mentality), Lohvinaú, Minsk. 
Azaryahu M., 1996, The power of commemorative street names, Environmental and Planning D: Society and Space, 14(3), 311-330. doi: 10.1068/d140311

Azaryahu M., 2011, The Critical Turn and Beyond: The Case of Commemorative Street Naming, ACME: An International EJournal for Critical Geographies, 10(1), 28-33.

Azaryahu M., 2019, King George or King David? Renaming the Colonial Past in Israel, Zeitgeschichte, 46(1), 15-37. doi: 10.14220/zsch.2019.46.1.15

Babkoú I., 1999, Ėtyka pamežža: Transkul'turnasc' âk belaruski dos'ved (Eng. The ethics of borderland: transculturality as Belarusian experience), Fragmenty, 1-2, https:// knihi.com/storage/frahmenty/6babkow2.htm (accessed 10 June 2020).

Basik S., Rahautsou D., 2019, Toponymic politics and the symbolic landscapes of Minsk, Belarus, Geographia Cassoviensis, 13(2), 107-120. doi: 10.33542/GC2019-2-02.

Basik S.N., Rogovcov D.A., 2003, Osobennosti formirovaniâ političeskoj toponimii (Eng. The features of the political toponymy formation), Vesnik Magilëúskaġa dzâržaúnaġa universtèta imâ A. A. Kulâšova, 2-3, 46-50.

Basik S.N., Rogovcov D. A., 2017, Politika i praktika toponimičeskoj nominacii $v$ kontekste nacional'noj političeskoj simvoliki Belarusi: teoretiko-konceptual'nyj aspect (Eng. The politics and practice of the toponymic nomination in the context of national political symbols of Belarus: theoretical and conceptual aspect), Vesnik of the Yanka Kupala State University of Grodno. Series 1. History and Archeology. Philosophy. Political Science, 9(3), 116-123.

Bekus N., 2017a, 'Constructed "Otherness"? Poland and the Geopolitics of Contested Belarusian Identity', Europe-Asia Studies, 69(2), 242-261. D doi: $10.1080 / 09668136.2017 .1295022$

Bekus N., 2017b, Ideological Recycling of the Socialist Legacy. Reading Townscapes of Minsk and Astana, Europe-Asia Studies, 69(5), 794-818. doi: 10.1080/09668136.2017.1350259

Berg L., Vuolteenaho J. (eds.), 2009, Critical toponymies: the contested politics of place naming, Ashgate, Farnham Burlington.

Bigon L. (ed.), 2016, Place Names in Africa: Colonial Urban Legacies, Entangled Histories, Springer International Publishing AG, Cham.

Bigon L., Njoh A.J., 2015, The Toponymic Inscription Problematic in Urban Sub-Saharan Africa: From Colonial to Postcolonial Times, Journal of Asian and African Studies, 50(1), 25-40. doi: 10.1177/0021909613510246

Bobkov I., 2008, Refleksii na polâh kritiki znaniâ: Vostočnoevropejskoe pogranič'e (Eng. Reflections on the Margins of the Critique of Knowledge: East European Borderland), Perekrëstki, 1, 5-12.

Chelcea L., Druță O., 2016, Zombie socialism and the rise of neoliberalism in post-socialist Central and Eastern Europe, Eurasian Geography and Economics, 57(4-5), 521544. doi: 10.1080/15387216.2016.1266273

David J., 2011, Commemorative Place Names - Their Specificity and Problems, Names, 59(4), 214-228. doi: 10.1179/00 $2777311 \times 13082331190074$
Demska O., 2016, Sučasnyj toponimnyj landšaft Ukraïny: miž pam'âttû I spogadom (Eng. Modern Toponymic Landscape of Ukraine: Between Memory and Remembrance), Slavia Orientalis, 65(3), 601-611.

Fiut A., 2014, In the Shadow of Empires: Postcolonialism in Central and Eastern Europe - Why Not? Teksty Drugie, Special Issue - English Edition, 1, 34-40.

Forest B., Johnson J., 2002, Unraveling the Threads of History: Soviet-Era Monuments and Post-Soviet National Identity in Moscow, Annals of the Association of American Geographers, 92(3), 524-547. doi: 10.1111/1467-8306.00303

Ġardzeâú Û., 2017, Urbananimičny dyskurs u pastsaveckaj Belarusi (Eng. Urbanonymic discourse in the post-Soviet Belarus), Acta Baltico-Slavica, 41, 212-250. doi: 10.11649/ abs.2017.009

Giraut F., Houssay-Holzschuch M., 2016, Place naming as dispositif: toward a theoretical framework, Geopolitics, 21(1), 1-21. doi: 10.1080/14650045.2015.1134493

Gnatiuk O., 2018, The renaming of streets in post-revolutionary Ukraine: regional strategies to construct a new national identity, AUC Geographica, 53(2), 119-136. doi: $10.14712 / 23361980.2018 .13$

Grabar H.S., 2014, Reclaiming the city: changing urban meaning in Algiers after 1962, Cultural Geographies, 21(3), 389409. doi: 10.1177/1474474013506361

Horsman S., 2006, The politics of toponyms in the Pamir mountains, Area, 38(3), 279-291. doi: 10.1111/j.14754762.2006.00697.x

Hui D.L.H., 2019, Geopolitics of Toponymic Inscription in Taiwan: Toponymic Hegemony, Politicking and Resistance, Geopolitics, 24(4), 916-943. doi: 10.1080/14650045.2017.1413644

Kapur A., 2019, Mapping place names of India, Routledge, Abingdon-New York.

Kołodziejczyk D., Şandru C., 2012, Introduction: On colonialism, communism and east-central Europe - some reflections, Journal of Postcolonial Writing, 48(2), 113-116. doi: 10.1080/17449855.2012.658242

Lazarus N., 2012, Spectres Haunting: Postcommunism and Postcolonialism, Journal of Postcolonial Writing, 48(2), 117-129.

Lehr J.C., McGregor B., 2016, The politics of toponymy: naming settlements, municipalities and school districts in Canada's Prairie provinces, Prairie Perspectives: Geographical Essays, 18, 78-84.

Lemcûgiova V.P., 2010, Pradmova (Eng. Preface), [in:] Nazvy naselenyh punktaú Rèspubliki Belarus'. Brèsckaâ Voblasc. (Eng. The names of settlements of the Republic of Belarus. Brest Region), Tèhnalogiiâ, Minsk, 7-23.

Lewis S., 2019, Belarus - Alternative Visions Nation, Memory and Cosmopolitanism, Routledge, Abingdon - New York.

Light D., Young C., 2017, The politics of toponymic continuity: the limits of change and the ongoing lives of the street names. [in] R. Rose-Redwood, D. Alderman, M. Azaryahu (eds.), The political life of urban streetscapes: naming, politics, and place, Routledge, Abingdon - New York, 185-201.

Marin A., 2017, Toponymic changes as temporal boundarymaking: Street renaming in Leningrad/St. Petersburg, [in] R. Rose-Redwood, D. Alderman, M. Azaryahu (eds.), 
The political life of urban streetscapes: naming, politics and space, Routledge, Abingdon - New York, 132-149.

Moore D.C., 2001, Is the Post- in Post-colonial the Post- in Post-Soviet? Toward a Global Post-colonial Critique, Publications of the Modern Language Association, 116(1), 111-128.

Nash C., 1999, Irish Place-names: Post-colonial Locations, Transactions of the Institute of British Geographers, 24(4), 457-480. DOI:10.1111/j.0020-2754.1999.00457.x

Oushakine S.A., 2013, Post-colonial Estrangements: Claiming a Space Between Stalin and Hitler, [in] J. Buckler, E.D. Johnson (eds.), Rites of Place: Public Commemoration in Russia and Eastern Europe, Northwestern University Press, Evanston, 285-315.

Oushakine S.A., 2017, How to Grow out of Nothing: The Afterlife of National Rebirth in Postcolonial Belarus, Qui Parle, 26(2), 423-490. doi:10.1215/10418385-4208451

Rose-Redwood R., Alderman D., Azaryahu M., 2017, The urban streetscape as political cosmos, [in] R. Rose-Redwood, D. Alderman, M. Azaryahu (eds.), The political life of urban streetscapes: naming, politics, and place, Routledge, Abingdon - New York, 1-24.

Rudling P., 2014, The Rise and Fall of Belarusian Nationalism, 1906-1931, University of Pittsburgh Press, Pittsburgh.

Rusu M.S., 2020, Political patterning of urban namescapes and post-socialist toponymic change: A quantitative analysis of three Romanian cities, Cities. doi: 10.1016/j.cities.2020.102773

Saparov A., 2017, Contested spaces: the use of place-names and symbolic landscape in the politics of identity and legitimacy in Azerbaijan, Central Asian Survey, 36(4), 534554. doi: 10.1080/02634937.2017.1350139

Shelekpayev N., 2017, Is Name Destiny? On Some Cases of Post-Soviet Street-Naming in Almaty and Astana, [in:] J. Ira, J. Janáč (eds.), Materializing Identities in Socialist and Post-Socialist Cities, Charles University in Prague, Karolinum Press, Prague, 99-115.

Stiperski Z., Lorber L., Heršak E., Ptaček P., Górka Z., Kołoś A., Lončar J., Faričić J., Miličević M., Vujaković A., Hršuka A., 2011, Identity through urban nomenclature: eight Central European cities, Geografisk Tidsskrift - Danish Journal of Geography, 111(2), 181-194. doi: 10.1080/00167223.2011.10669532

The Roman alphabet transliteration of Belarusian geographical names, 2012, Tenth United Nations Conference on the Standardization of Geographical Names New York, the 31st of July - the 9th of August 2012. https://unstats.un.org/ unsd/geoinfo/UNGEGN/docs/10th-uncsgn-docs/crp/E_ CONF.101_CRP2_The\%20Roman\%20alphabet\%20transliteration.pdf (accessed 10 June 2020).

Tucker B., Rose-Redwood R., 2015, De-colonizing the map? Toponymic politics and the rescaling of the Salish Sea, The Canadian Geographer/Le Géographe Canadien, 59(2), 194-206. DOI: 10.1111/cag.12140

V Nacional'nom Kadastrovom Agenstve sostavili rejting samyh populârnyh nazvanij ulic (Eng. The National Cadastral Agency ranked the most popular street names in Belarus), 2019, https://www.belta.by/society/view/v-natsionalnom-kadastrovom-agentstve-sostavili-rejting-samyh- populjarnyh-v-belarusi-nazvanij-ulits-353880-2019/ (accessed 10 June 2020).

Vuolteenaho J., Berg L.D., 2009, Towards critical toponymies, [in] L. Berg, J. Vuolteenaho (eds.), Critical toponymies: the contested politics of place naming, Ashgate, Farnham Burlington, 1-18.

Wanjiru-Mwita M., Giraut F., 2020, Toponymy, Pioneership, and the Politics of Ethnic Hierarchies in the Spatial Organization of British Colonial Nairobi, Urban Science, 4, 6. https://www.mdpi.com/2413-8851/4/1/6 (accessed 10 June 2020).

Yeoh B., 1996, Street names and nation-building: toponymic inscriptions of nationhood, Area, 28(3), 298-307.

Yeoh B.S.A., 1992, Street names in colonial Singapore, The Geographical Review, 82, 313-322.

Žučkevič V.A., 1974, Kratkij toponimičeskij slovar' Belorussii (Eng. A short toponymic dictionary of Byelorussia), BGU, Minsk. 